\title{
Screening of in vitro antimicrobial effects of Helicteres isora extract against Staphylococcus aureus
}

\author{
Sunisa Sirimongkolvorakul1(i) and Anusorn Jasancheun ${ }^{2}$
}

1. Department of Pre-Clinical Veterinary Science, Faculty of Veterinary Medicine, Mahanakorn University of Technology, 140 Cheum-Sampan Rd., Nong Chock, Bangkok 10530 Thailand; 2. A.T. Animal Clinic 284/3 Village No. 13, Kaset Wisai Roi Et, Thailand.

Corresponding author: Sunisa Sirimongkolvorakul, e-mail: sirikul_sunii@yahoo.com

Co-author: AJ: anusorn.vet@gmail.com

Received: 15-03-2021, Accepted: 30-07-2021, Published online: 04-09-2021

doi: www.doi.org/10.14202/vetworld.2021.2313-2316 How to cite this article: Sirimongkolvorakul S, Jasancheun A (2021) Screening of in vitro antimicrobial effects of Helicteres isora extract against Staphylococcus aureus, Veterinary World, 14(9): 2313-2316.

\begin{abstract}
Background and Aim: Staphylococcus aureus is an important pathogen causing contagious mastitis in cows that need novel treatment rather than antibiotic therapy. This study aimed to investigate the antimicrobial activity of Helicteres isora extracts against $S$. aureus isolated from subclinical and clinical mastitis cows using an in vitro model.
\end{abstract}

Materials and Methods: H. isora pods were extracted using the following solvents: Distilled water, ethanol, acetone, and methanol. The antimicrobial activity of each extract was determined by the disk diffusion method and broth microdilution assay to assess the minimum inhibitory concentration (MIC) and minimum bactericidal concentration (MBC).

Results: The ethanolic extract of $H$. isora exhibited the largest inhibition zones against $S$. aureus $(31.05 \pm 1.20 \mathrm{~mm})$, followed by the aqueous, methanolic, and acetone extracts, respectively $(26.34 \pm 1.15,24.23 \pm 0.50$, and $22.46 \pm 1.53)$. The ethanolic extract also had a strong inhibitory effect on $S$. aureus, with MIC and MBC of 0.13 and $0.52 \mathrm{mg} / \mathrm{mL}$, respectively.

Conclusion: This study revealed that $H$. isora is a potential alternative natural antibacterial agent against $S$. aureus infection. The antimicrobial activity of $H$. isora is most likely mediated by phytochemical constituents.

Keywords: antimicrobial, Helicteres isora, herbs, mastitis, Staphylococcus aureus.

\section{Introduction}

Mastitis is economically important in dairy cows worldwide. Mastitis affects animal health, reduces milk quality, decreases milk yield, and shortens the productive life of affected cows [1,2]. Based on pathogens, mastitis can be divided into contagious and environmental pathogens [3]. Staphylococcus aureus is an important pathogen causing contagious mastitis characterized by lower cure rates than other pathogens $[4,5]$. The treatment of mastitis includes antibiotic use. However, the inappropriate use of antibiotics has led to many forms of bacterial resistance.

Research has focused on the potential of natural products in the treatment of mastitis, particularly S. aureus infection. Among herbs, Helicteres isora L. has shown medicinal importance. H. isora is also known as the Indian screw tree. It demonstrates various health benefits, including anticancer activity $[6,7]$, antibacterial and antiplasmid activities [8], and cardiac antioxidant and antiperoxidative potency [9].

Copyright: Sirimongkolvorakul and Jasancheun. Open Access. This article is distributed under the terms of the Creative Commons Attribution 4.0 International License (http://creativecommons. org/licenses/by/4.0/), which permits unrestricted use, distribution, and reproduction in any medium, provided you give appropriate credit to the original author(s) and the source, provide a link to the Creative Commons license, and indicate if changes were made. The Creative Commons Public Domain Dedication waiver (http:// creativecommons.org/publicdomain/zero/1.0/) applies to the data made available in this article, unless otherwise stated.
Therefore, this study aimed to investigate the antimicrobial activity of $H$. isora extract against $S$. aureus isolated from subclinical and clinical mastitis cows using an in vitro model. Furthermore, the active $H$. isora extracts were investigated for their phytochemical contents.

\section{Materials and Methods}

\section{Ethical approval}

Ethical approval was not necessary for this study as the milk samples were collected from lactating dairy cows from a private farm as per standard collection procedure.

\section{Study period and location}

This study was conducted in April 2018. Milk samples were obtained from lactating cows from a private farm, Chachoengsao, Thailand. Then S. aureus was isolated and identified at Veterinary Diagnostic Center, Faculty of Veterinary Medicine, Mahanakorn University of Technology.

\section{Microbial sample collection}

S. aureus was isolated from subclinical and clinical mastitis cows in Chachoengsao, Thailand. Isolates were identified by pure culture and biochemical tests. S. aureus ATCC II 25923 was used as a standard strain throughout the study.

\section{Preparation of extracts}

H. isora pods were collected from Chachoengsao, Thailand. The herbs were identified by faculty member, 
Faculty of Pharmacy, Mahidol University, Bangkok, Thailand (Voucher no.PBM05249). Whole pods were washed several times with tap water, shade-dried (Thelco ${ }^{\circledR}, \mathrm{GCA} /$ Precision Scientific, USA) at $45^{\circ} \mathrm{C}$ for $72 \mathrm{~h}$, and ground into powder using a mixer blender (Otto, Thailand). Powdered H. isora (8 g) was soaked in distilled water, ethanol, acetone, and methanol. The plant material was left to stand at $37^{\circ} \mathrm{C}$ for $72 \mathrm{~h}$ and subsequently filtered through Whatman No. 1 . The filtered extract was dried for $24 \mathrm{~h}$ using a freeze dryer (Supermodulyo-230, Thermo Scientific, USA).

\section{Determination of phytochemical constituents in $H$. isora extracts}

The total phenolic content was determined by Folin-Ciocalteu assay [10] using gallic acid (GA) as a standard and expressed as $\mathrm{mg} / \mathrm{g}$ GA equivalents (GAEs). Briefly, $0.5 \mathrm{~mL}$ extract $(2.5 \mathrm{mg} / \mathrm{mL})$ was mixed with $2.5 \mathrm{~mL}$ of $10 \%$ Folin-Ciocalteu reagent and $2 \mathrm{~mL}$ of $0.7 \mathrm{M}$ sodium carbonate. The mixture was allowed to stand for $2 \mathrm{~h}$ at $37^{\circ} \mathrm{C}$ (room temperature), and absorbance was measured by a spectrophotometer at $765 \mathrm{~nm}$ against distilled water as a blank. The results were expressed as $\mathrm{mg} / \mathrm{g}$ GAE. All samples were analyzed in triplicate.

Flavonoid contents were determined based on the colorimetric aluminum chloride $\left(\mathrm{AlCl}_{3}\right)$ method [10]. Briefly, $0.5 \mathrm{~mL}$ of extract was mixed with $0.1 \mathrm{~mL}$ of $10 \% \mathrm{AlCl}_{3}, 0.1 \mathrm{~mL}$ of $1 \mathrm{M}$ potassium acetate, and $2.8 \mathrm{~mL}$ distilled water and left at room temperature for $30 \mathrm{~min}$. The absorbance of the reaction mixture was measured at $415 \mathrm{~nm}$. Total flavonoid contents were calculated as quercetin from a calibration curve. Quercetin in methanol was used for calibration curve preparation.

Tannin contents were determined based on a colorimetric assay [11]. Briefly, $2 \mathrm{~mL}$ extract was mixed with $2 \mathrm{~mL}$ of $0.1 \mathrm{M} \mathrm{FeCl}_{3}$ in $0.1 \mathrm{~N} \mathrm{HCl}$ and $0.008 \mathrm{M}$ potassium ferrocyanide. Absorbance was measured by a spectrophotometer at $120 \mathrm{~nm}$. The results were expressed as mg/g GAE. All samples were analyzed in triplicate.

Alkaloid contents were determined based on a colorimetric method [11]. Briefly, $2 \mathrm{~mL}$ extract was mixed with $20 \%$ acetic acid and evaporated using a water bath. Concentrated ammonium was added dropwise to the extract until precipitation was complete.

\section{Determination of antimicrobial activity}

The disk diffusion method was used for the primary screening of antibacterial activity of each extract [12]. A $10 \mu 1(133 \mathrm{mg} / \mathrm{mL})$ aliquot of each extract was individually applied to a sterile filter paper disk (Whatman No. 1; $8 \mathrm{~mm}$ in diameter). The disks were placed on Mueller-Hinton agar (MHA) plates previously seeded with the test bacteria $\left[10^{8}\right.$ colony-forming units $\left.(\mathrm{CFU}) / \mathrm{mL}\right]$. Antibiotic susceptibility disk ( $5 \mu \mathrm{L}$ ampicillin/disk) was used as a control, whereas $10 \mu \mathrm{L}$ dimethyl sulfoxide (DMSO) was included as a negative control.
The plates were incubated at $37^{\circ} \mathrm{C}$ for $24 \mathrm{~h}$. Antibacterial activity was evaluated by measuring the diameter $(\mathrm{mm})$ of the inhibition zone. All tests were conducted in triplicates, and the mean diameter of the inhibition zone was calculated.

The minimum inhibitory concentration (MIC) and minimum bactericidal concentration (MBC) were determined by a modified broth microdilution assay [13]. The stock solution of each extract was prepared in DMSO. Two-fold serial dilutions of the extract were filtered through $0.45 \mu \mathrm{m}$ Millipore filters and prepared at test concentrations from 66.5 to $0.13 \mathrm{mg} / \mathrm{mL}$ with an inoculum size of $1.5 \times 10^{7}$ $\mathrm{CFU} / \mathrm{mL} S$. aureus. The lowest concentration of the extracts that showed no visible growth after $24 \mathrm{~h}$ incubation at $37^{\circ} \mathrm{C}$ was considered MIC. The positive growth of microorganisms cultured in Mueller Hinton Broth without test extracts served as a control. An aliquot of the mixture of the test extracts and bacterial suspension without turbidity after $24 \mathrm{~h}$ incubation was inoculated on MHA. To adjust the interference by plant pigments, a series of mixtures with uninoculated broth were prepared. The lowest concentration of the test extracts that showed no growth on agar was defined as MBC. Triplicate samples were performed for each concentration.

\section{Statistical analysis}

Data were calculated as the mean \pm standard deviation. Analysis of variance was performed for each group. The significance of differences was considered when $\mathrm{p} \leq 0.05$.

\section{Results}

\section{Antimicrobial assay}

The possibility of $H$. isora as an alternative antibacterial agent was tested. All test extracts of $H$. isora showed antimicrobial activity, inhibiting the growth of $S$. aureus. The ethanolic extract of $H$. isora exhibited the largest inhibition zones against $S$. aureus $(31.05 \pm 1.20 \mathrm{~mm})$, followed by the aqueous, methanolic, and acetone extracts, respectively $(26.34 \pm 1.15$, $24.23 \pm 0.50$, and $22.46 \pm 1.53$ ).

The efficacy of $H$. isora extract against S. aureus was investigated in terms of MIC and MBC using a broth microdilution assay. Table-1 shows the MIC values of each extracted sample. The ethanolic extract also had a strong inhibitory effect on S. aureus, with MIC and MBC of 0.13 and $0.52 \mathrm{mg} / \mathrm{mL}$, respectively. Furthermore, the standard strain was more sensitive to $H$. isora than the clinical isolates. Moreover, the ethanolic extract of $H$. isora exhibited the highest concentration of phenolics and flavonoids, followed by the methanolic, acetone, and aqueous extracts. In contrast, the highest concentration of alkaloids and tannins was found in the aqueous extract. These findings indicated that the active compounds of $H$. isora extracts are different depending on the solvent used. 


\section{Phytochemical analysis}

The preliminary phytochemical screening of each extract revealed a good source of tannins, phenolics, alkaloids, and flavonoids, and their quantities showed solvent-dependent variation (Table-2).

\section{Discussion}

Various herbs are studied for their potential antimicrobial effects against pathogens, including $H$. isora. This study showed that the ethanol extract of $H$. isora and its constituents could be effective against $S$. aureus. H. isora extracts showed clear inhibition zones against $S$. aureus in the disk diffusion method. Furthermore, MIC and MBC demonstrated that $H$. isora extracts possessed antibacterial activity against clinic isolated bovine mastitis $S$. aureus, and their mechanism remains unknown. Notably, the ethanolic extract of $H$. isora exhibited the highest phenolics and flavonoids, whereas the aqueous extract of $H$. isora displayed the highest alkaloids and tannins. Thus, the antimicrobial properties of $H$. isora extracts may be due to the presence of flavonoids and other compounds. This finding was similar to several studies that reported that active compounds in peels, fruits, or seeds in herbs, such as phenolics, flavonoids, and tannins, exhibit antimicrobial activity. Indeed, flavonoids have shown antimicrobial effects against a wide range of organisms. Flavonoids have strong antimicrobial activity due to the structure-function relationship of flavonoids, thereby inhibiting the growth of microorganisms [14]. The ethanolic extract of grape pomace had antimicrobial activity against Enterobacteriaceae, S. aureus, Salmonella,

Table-1: MIC and MBC of $\mathrm{H}$. isora extract against S. aureus.

\begin{tabular}{|c|c|c|c|c|}
\hline \multirow{2}{*}{$\begin{array}{l}\text { Type of } \\
\text { solvent } \\
\text { extract }\end{array}$} & \multicolumn{2}{|c|}{ Isolated S. aureus } & \multicolumn{2}{|c|}{$\begin{array}{c}\text { S. aureus ATCC II } \\
25923\end{array}$} \\
\hline & $\begin{array}{c}\text { MIC } \\
(\mathrm{mg} / \mathrm{mL})\end{array}$ & $\begin{array}{c}M B C \\
(\mathrm{mg} / \mathrm{mL})\end{array}$ & $\begin{array}{c}\text { MIC } \\
(\mathrm{mg} / \mathrm{mL})\end{array}$ & $\begin{array}{c}\text { MBC } \\
(\mathrm{mg} / \mathrm{mL})\end{array}$ \\
\hline Methanol & 33.25 & $>66.5$ & 16.63 & 33.25 \\
\hline Ethanol & 0.26 & 0.52 & 0.13 & 0.52 \\
\hline Acetone & $>66.5$ & $>66.5$ & $>66.5$ & $>66.5$ \\
\hline Water & 0.52 & 2.08 & 0.26 & 1.04 \\
\hline
\end{tabular}

MIC=Minimum inhibitory concentration, $\mathrm{MBC}=$ Minimum bactericidal concentration, $H$. isora=Helicteres isora, S. aureus=Staphylococcus aureus

Table-2: Phytochemical presence of $H$. isora extract.

\begin{tabular}{|c|c|c|c|c|}
\hline \multirow{2}{*}{$\begin{array}{l}\text { Type of } \\
\text { solvent } \\
\text { extract }\end{array}$} & \multicolumn{4}{|c|}{ Phytochemicals } \\
\hline & $\begin{array}{c}\text { Phenolics }^{1} \\
(\text { mean } \pm S E)\end{array}$ & $\begin{array}{l}\text { Flavonoids }^{2} \\
(\text { mean } \pm S E)\end{array}$ & $\begin{array}{c}\text { Tannins }^{1} \\
(\operatorname{mean} \pm S E)\end{array}$ & $\begin{array}{c}\text { Alkaloids }^{3} \\
\text { (mean } \\
\text { SE) }\end{array}$ \\
\hline Methanol & $36.52 \pm 1.5$ & $32.25 \pm 1.1$ & $1.02 \pm 0.5$ & $1.60 \pm 0.1$ \\
\hline Ethanol & $42.16 \pm 1.3$ & $25.17 \pm 0.8$ & $1.32 \pm 0.3$ & $1.8 \pm 0.5$ \\
\hline Acetone & $17.30 \pm 0.8$ & $12.56 \pm 0.5$ & $0.94 \pm 0.1$ & $1.09 \pm 0.4$ \\
\hline Water & $28.71 \pm 1.1$ & $16.30 \pm 1.2$ & $2.80 \pm 0.2$ & $3.2 \pm 0.2$ \\
\hline
\end{tabular}

Values were performed in triplicated and represented as mean \pm SE. ${ }^{1} \mathrm{mg}$ GAE$/ 100 \mathrm{~g}$ extract, ${ }^{2} \mathrm{mg}$ QUE $/ 100 \mathrm{~g}$ extract, ${ }^{3} \mathrm{mg} \mathrm{DE} / 100 \mathrm{~g}$ extract. $\mathrm{H}$. isora=Helicteres isora, $\mathrm{GAE}=$ Gallic acid equivalent yeast, and molds [15]. Mango kernel extracts exhibited antimicrobial spectrum against Gram-positive and Gram-negative bacteria, such as S. aureus, Bacillus subtilis, and Escherichia coli [16]. Similarly, the phenolic extracts of honey had strong antimicrobial activity against $E$. coli, followed by $S$. aureus, Enterococcus faecalis, and Pseudomonas aeruginosa [12]. Studies that investigated the antimicrobial activity of various herbs against $S$. aureus have also been reported. The essential oil of Eucalyptus globulus leaves had antimicrobial effects as determined by disk diffusion and dilution broth methods [17]. Similarly, cinnamon essential oil exhibited antibacterial activity against $S$. aureus (MIC=1.0 mg/mL), and the mechanism changes membrane permeability and integrity [18]. Honey from different botanical origins also had different MICs against S. aureus [19]. Litsea cubeba essential oil showed good antibacterial effects against methicillin-resistant $S$. aureus (MRSA) by destructing the MRSA cell membrane, leading to intracellular biological macromolecular leakages [20]. Nevertheless, several studies demonstrated that the antimicrobial activity of herbs could vary depending on the extraction method, inoculum size, and determination method [21].

\section{Conclusion}

This study revealed that $H$. isora is a potential alternative natural antibacterial agent against $S$. aureus infection. The antimicrobial activity of $H$. isora is most likely mediated by phytochemical constituents.

\section{Authors' Contributions}

SS and AJ: Designed and managed the study. AJ: Performed sample collections. SS and AJ: Data collection and analysis. SS: Drafted the manuscript. All authors participated in the revision of this manuscript and approved the submission.

\section{Acknowledgments}

We are thankful to the dairy farmers in Chachoengsao, Thailand, for their cooperation during the study. This project was partially supported by Faculty of Veterinary Medicine, Mahanakorn University of Technology, Thailand.

\section{Competing Interests}

The authors declare that they have no competing interests.

\section{Publisher's Note}

Veterinary World remains neutral with regard to jurisdictional claims in published institutional affiliation.

\section{References}

1. Hogeveen, H. and van, MDV. (2017) Assessing the economic impact of an endemic disease: The case of mastitis. Rev. Sci. Tech., 36(1): 217-226.

2. Wang, W., Lin, X., Jiang, T., Peng, Z., Xu, J., Yi, L., Li, F., Fanning, S. and Baloch, Z. (2018) Prevalence and characterization of Staphylococcus aureus cultured from raw 
milk taken from dairy cows with mastitis in Beijing, China. Front. Microbiol., 9: 1123.

3. Neiwert, O., Holst, O. and Duda, K.A. (2014) Structural investigation of rhamnose-rich polysaccharides from Streptococcus dysgalactiae bovine mastitis isolate. Carbohydr. Res., 389(7): 192-195.

4. Levison, L.J., Miller-Cushon, E.K., Tucker, A.L., Bergeron, R., Leslie, K.E., Barkema, H.W. and DeVries, T.J. (2016) Incidence rate of pathogen-specific clinical mastitis on conventional and organic Canadian dairy farms. J. Dairy Sci., 99(2): 1341-1350.

5. Poutrel, B., Bareille, S., Lequeux, G. and Leboeuf, F. (2018) Prevalence of mastitis pathogens in France: Antimicrobial susceptibility of Staphylococcus aureus, Streptococcus uberis and Escherichia coli. J. Vet. Sci. Technol., 9(2): 1-3.

6. Varghese, E., Narayanan, S.S., Gopal, R.V., Nair, A., Chittethu, A.B. and Anson, T.A. (2011) Anticancer activity of chloroform extract of Helicteres isora. Int. J. Pharm. Technol., 3(2): 2560-2564.

7. Rattanamaneerusmee, A., Thirapanmethee, K., Nakamura, Y., Bongcheewin, B. and Chomnawang, M.T. (2018) Chemopreventive and biological activities of Helicteres isora L. fruit extracts. Res. Pharm. Sci., 13(6): 484-492.

8. Shriram, V., Jahagirdar, S., Latha, C., Kumar, V., Dhakephalkar, P., Rojatkar, S. and Shitole, M.G. (2010) Antibacterial and antiplasmid activities of Helicteres isora L. Indian J. Med. Res., 132(7): 94-99.

9. Kumar, G., Banu, G.S. and Murugesan, A.G. (2008) Effect of Helicteres isora bark extracts on heart antioxidant status and lipid peroxidation in streptozotocin diabetic rats. $J$. Appl. Biomed., 6(2): 89-95.

10. Alhakmani, F., Kumar, S. and Khan, S.A. (2013) Estimation of total phenolic content, in vitro antioxidant and anti-inflammatory activity of flowers of Moringa oleifera. Asian Pac. J. Trop., 3(8): 623-627.

11. Ali, S., Khan, M.R., Irfanullah, Sajid, M. and Zahra, Z. (2018) Phytochemical investigation and antimicrobial appraisal of Parrotiopsis jacquemontiana (Decne) Rehder. BMC Complement. Altern. Med., 18(1): 43.

12. Leyva-Jimenez, F.J., Lozano-Sanchez, J., BorrasLinares, I., Cadiz-Gurrea, M.L. and Mahmoodi-Khaledi, E.
(2019) Potential antimicrobial activity of honey phenolic compounds against Gram-positive and Gram-negative bacteria. LWT Food Sci. Technol., 101: 236-245.

13. Alshaibani, D., Zhang, R. and Wu, V.C.H. (2017) Antibacterial characteristics and activity of Vaccinium macrocarpon proanthocyanidins against diarrheagenic Escherichia coli. J. Funct. Foods, 39: 133-138.

14. Cueva, C., Moreno-Arribas, M.V., Martín-Álvarez, P.J., Bills, G., Vicente, M.F., Basilio, A., Rivas, C.L., Requena, T., Rodríguez, J.M. and Bartolomé, B. (2010) Antimicrobial activity of phenolic acids against commensal, probiotic and pathogenic bacteria. Res Microbiol., 161(5): 372-382.

15. Sagdic, O., Ozturk, I., Yilmaz, M.T. and Yetim, H. (2011) Effects of grape pomace extracts obtained from different grape varieties on microbial quality of beef patty. J. Food Sci., 76(7): M515-M525.

16. Engels, C., Knödler, M., Zhao, Y.Y., Carle, R., Gänzle, M.G. and Schieber, A. (2009) Antimicrobial activity of gallotannins isolated from mango (Mangifera indica L.) kernels. $J$. Agric. Food. Chem., 57(17): 7712-7718.

17. Bachir, R.G. and Benali, M. (2012) Antibacterial activity of the essential oils from the leaves of Eucalyptus globulus against Escherichia coli and Staphylococcus aureus. Asian Pac. J. Trop., 2(9): 739-742.

18. Zhang, Y., Liu, X., Wang, Y., Jiang, P. and Quek, S. (2016) Antibacterial activity and mechanism of cinnamon essential oil against Escherichia coli and Staphylococcus aureus. Food Control, 59: 282-289.

19. Osés, S.M., Pascual-Maté, A., de la Fuente, D., de Pablo, A., Fernández-Muiño, M.A. and Sancho, M.T. (2016) Comparison of methods to determine antibacterial activity of honeys against Staphylococcus aureus. NJAS Wageningen J. Life Sci., 78(1): 29-33.

20. Hu, W., Li, C., Dai, J., Cui, H. and Lin, L. (2019) Antibacterial activity and mechanism of Litsea cubeba essential oil against methicillin-resistant Staphylococcus aureus (MRSA). Ind. Crops Prod., 130: 34-41.

21. Tajkarimi, M.M., Ibrahim, S.A. and Cliver, D.O. (2010) Antimicrobial herb and spice compounds in food. Food Control, 21(9): 1199-1218. 